\title{
JOB SATISFACTION IN PROJECT-BASED ORGANIZATION
}

\author{
Magdalena GĘBCZYŃSKA \\ Silesian University of Technology, Faculty of Organization and Management; Magdalena.Gebczynska@polsl.pl, \\ ORCID: 0000-0002-0463-0144
}

Purpose: the purpose of this article is to examine how different factors, such as: person organization fit, supervisor support, rewards, organizational commitment and work engagement simultaneously affect the employee job satisfaction in project-based organization.

Design/methodology/approach: This research applies fuzzy set Qualitative Comparative Analysis (fs/QCA). The sample of the study includes 17 cases of Polish consulting firms, and the fieldwork contains information from series of surveys. The survey includes five scales (person organization fit, supervisor support, rewards, organizational commitment and work engagement) in the form of statements to which respondents indicate their level of agreement/disagreement on a five-point Likert scale.

Findings: empirical research indicated the configurations of factors which lead to job satisfaction in $\mathrm{PBO}$, pecially, (C1): person organization fit, supervisor support and organizational commitment and (C2): rewards, organizational commitment and work engagement with absence of supervisor support and (C3): person organization fit, rewards and work engagement influence job satisfaction in project-based organization.

Research limitations/implications: the first limitation relates to the data source - the data in this study come from a limited research sample-consulting firms. Second, this study considered and examined few factors of job satisfaction selected based on critical analysis of the literature and future studies could include other variables.

Practical implications: the results of research have practical implications for managers of project-based organization, because they provide them with configuration of factors which lead to job satisfaction.

Originality/value: using of fs/QCA, which enabled simultaneous studying the effect of selected factors and it is an original contribution to the research on job satisfaction in PBO.

Keywords: job satisfaction, project-based organization, Qualitative Comparative Analysis.

Category of the paper: research paper. 


\section{Introduction}

Project-based organizations (PBO) are an important element and are increasingly widespread in modern economy and society (Cattani et al., 2011; Lundin et al., 2015). In the literature, it is widely emphasized, that project-based organizations are particularly needed in significantly customized, such as: software development (Ibert, 2004), engineering design (Cacciatori, 2008), biotechnology (Ebers, and Powell, 2007), complex products and systems (Hobday, 1998) and film-making and media (Sydow and Windeler, 1998). Projectbased organizations are becoming dominant, even in industries where the activity was not based on projects, i.e. for example: healthcare (Aubry et al., 2014), pharmaceuticals (Freilich, 2015) or computer technologies (Brown, and Eisenhardt, 1997; Loufrani-Fedida, and Saglietto, 2016).

PBO is different from the classical organization. The transition from classical organization that runs projects sometimes to project-based organization is difficult, but not impossible. There is few important issue, need to be solved by the classical organization during its transition to the project-based organization. The main of them are: to diminish the authority of hierarchical departmental managers and delegate authority and competences of project managers; to develop a mechanism for prioritization of projects and activities; to cluster projects for integrate of simultaneous multiple projects. Thiry and Deguire (2007) have identified three major issues to improve organizational structure in project-based organization: (1) a horizontal integration process of projects across the product life-cycle; (2) a vertical integration approach of projects across the project portfolio, to link it to the corporate strategy; (3) integrative project governance structures to create and deliver value. During this transition and improving organizational structure, one of the most important issue are employees of these organizations, who as one of stakeholders are usually ignored in organizations (Sharma et al., 2009). Employees are the most important assets of an organization and have a significance role in success or failure of an organization, so organizations need to focus on employees job satisfaction which will translate for more benefits for them.

Deming (2014) has stated that running a company based on visible figures only is one of the 'deadly management diseases', and this view certainly applies to project-based organizations. Project-based organizations refer to a variety of organizational forms that involve the creation of temporary systems for the performance of project tasks (Sydow et al., 2004). Definitions of project-based organizations are different, but a key point is that projectbased organizations possess all internal and external resources, as well as individual functions such as development, production and sales, and established organizations are structured to execute business as individual projects (Hobday, 2000). A characteristic that defines a projectbased organization is according to Bredin (2006) the high amount of educated and skilled employees in the project teams. Bredin (2006) state that competences of employees are the main 
competitive advantage, which implies that also the work situation of single employees becomes a critical strategic competitive factor.

Miterev et al. (2017) define the project based organization as one which makes the strategic decision to adopt project, program and project portfolio management as business processes to manage its work, and which views itself as being project-oriented. The basic problem of the project-based organization is to create organizational solutions that effectively combine two activities: the current activities of the parent organization and project activities and their organizational structures: a static, stable structure of the matrix organization focused primarily on the implementation of its repetitive tasks and the dynamic, temporary structure of the project focused on achieving its unique result (Trocki, 2016). Attempts to solve the problem of projectbased organization were undertaken in practice and in theory for a long time and led to the development of various solutions of the project-based organization, whose generalized form are model solutions of the project organization (Trocki, 2016): (1) functional project organization; (2) line-staff project organization; (3) matrix project organization; (4) weak/ balanced/strong; (5) pure project organization; (6) project company external project execution; (7) project consortium; (8) network project organization. Thiry and Deguire (2007) have identified three major issues to improve organizational structure at PBO level: (1) horizontal integration process of projects across the product life-cycle, (2) a vertical integration approach of projects across the project portfolio, to link it to the corporate strategy, (3) integrative project governance structures to create and deliver value.

Many organizations fail to understand the important of a working environment for employee job satisfaction and therefore, the organization face the difficulties in their activities (Raziq, and Maulabakhsh, 2015). People spend almost a half part of life in their work and they are the backbone of the organization. There are several definitions of job satisfaction: in some of these definitions, this concept defined as feeling and viewing reaction of employees to job (Snips et al., 2008). Satisfaction is of supreme importance for employees to stay happy even in the meager situation. The definition of job satisfaction is the enjoyable and emotional state resulting from the evaluation of one's job (Danish, and Usman, 2010) or job experiences; the employee feels fulfillment and pride in achieving the business's goals. Job satisfaction occurs when someone feels he/she has proficiency, value, and is worthy of recognition (Garcez, 2006). Job satisfaction affect an important issues such as: amount of delay, absence and service abandonment and also an individual efficiency and effectiveness such as amount of the production and productivity of man. Employees who feel satisfied with their jobs provide higher levels of customer satisfaction (Snips et al., 2008).

Job satisfaction is an essential factor that affects employees' initiative and enthusiasm. On the assumption that people are happy with their job and have the passion for it, their lives then become much enjoyable. With job satisfaction, an employee can feel his job is fun or not to work. A lack of job satisfaction can lead to increased absenteeism and unnecessary turnover in the workplace, because employees will choose to change employment when they do not 
achieve happiness and satisfaction on their job. Job satisfaction describes how content an individual is with his or her job. According to the (Chahal et al., 2013), job satisfaction view as any combination of physiological, environmental circumstance and psychological, which cause a person honorably, happy with his or her job.

Project-based organization's activity is to generate the results in response to specific client demands by creating projects within a fixed time limit. Good and quality employees are becoming an increasingly scarce resource and it is the employees engagement and work are factors which influence on and decide about success or failure of an organization. Employees interact with the customer on a day to day basis and carry out the whole operations, that's why organizations need to give more attention to the satisfaction of the employees. If the employee is satisfied towards the work then it is likely to yield more results. All organizations need to focus on employee satisfaction and know the factors that affect it. In case project-based organizations, this issue requires more attention and becomes more important, because projects have different constraints and require high-quality workforce and greater effort and input from employees.

The purpose of this article is to examine how different, chosen factors such as: person organization fit, supervisor support, rewards, organizational commitment and work engagement simultaneously affect the employee job satisfaction in project-based organization. This empirical research uses fuzzy set qualitative comparative analysis (fs/QCA) to explore the connections between employee job satisfaction and the chosen conditions. First, a brief review of the literature on a set of factors, namely the variables influencing the employee job satisfaction, is done. Then the methodology of research (fuzzy set Qualitative Comparative Analysis) is presented. The results of the analysis and the conclusion are discussed in the last section.

\section{Background literature}

Based on a broad and critical analysis of the literature, determinants of employee satisfaction were selected and will be discussed below.

Person organization fit has been an area of interest among both researchers and managers during recent years whose concern is the antecedents and consequences of compatibility between people and the organizations in which they work. Post 1970s researchers have started examining the role of person environment fit and its different facets such as: person organization fit, person job fit, person environment fit (Jansen, and Kristof, 2006; Cable, and Judge, 1996) and their influences on work attitudes, performance and job satisfaction. Despite the ever-changing work place and shifts in generational work attitudes, person-organization fit remains a significant influence in determining job satisfaction (Faroqui, and Nagendra, 2014). 
Person organization fit is widely understood as congruence between individual and organizational values (Santos, and Domenico, 2015). Employees are expected to get with the coworkers and fit within their work environment (Vianen et al., 2011), therefore person organization fit is also referred to as the compatibility of individual and organizational beliefs and values (Netemeyer et al., 1997), personality (Christiansen et al., 1997) and/or goals (Kristof, 1996). The benefits of person organization fit are: increased loyalty and increased productivity, and person organization fit is often explained also as the compatibility between people and the organizations in which they work (Kristof, 1996).

Rowold et al. (2014) propose that the leadership style of an employee's supervisor positively affects the employee's organizational commitment and job satisfaction. Anderson et al. (2002) have shown that supervisory support had a direct relationship with job satisfaction. According to Putter (2013), the support can be in terms of emotional or instrumental. Supervisor's feedback also are a form of supervisor support (van der Klink et al., 2001). Feedback from supervisor is seen as part of supervisor support whereby the supervisor identify which area of their employees needs to be improved. Cahill et al. (2015) found that supervisor support influences employee job satisfaction, employee engagement, organizational commitment, productivity and performance. Supervisor and coworker support are probably going to build workers' full of feeling and standardizing duty because of the enthusiastic bonds. Cahill et al. (2015) and Albrecht et al. (2015) state that supervisors should active participate building relationship to increase employee job satisfaction and employee engagement. Employees who perceive greater support have greater emotional and psychological resources for coping with stress (Hoonakker et al., 2013). Supervisor support is the degree to which employees perceive that supervisors care about their well-being (De Clercq et al., 2016).

Rewards and their connection with job satisfaction has always been an issue in the human resource management. Luthans and Sommers (2005) and Edwards et al. (2006) explained that rewards were received as an exchange of services between employee and employer. Reward is a broad construct that has been said to represent anything that an employee may value that an employer is willing to offer in exchange for his or her contributions (Chiang and Birtch, 2008). Rafikul and Ahmad (2008) implied that rewards significantly improves an employee's motivation towards their work and subsequently builds job satisfaction (Kiviniemi et al., 2002). Rewards cover both financial and non- financial issue. Financial rewards consist of payments in the form of wages, salaries and bonuses. Indirect financial rewards, or benefits, consist of e.g.: insurance plans (life, health), retirement plans and sick leave. Finally, the non-financial rewards consist of the satisfaction that a person receives from the job itself, from the psychological and physical environment in which the person works (Mondy, and Noe, 2002). Furthermore, non-financial rewards deal with feelings of recognition, achievement, responsibilities and personal growth (Armstrong, and Murlis, 2004). The research results indicate that the system of organizational awards plays a key role in increasing employee satisfaction. Organizations focus rather on financial rewards, and non-financial rewards are 
increasingly overlooked (Chiang, and Birtch, 2008). The second division include distinguish between intrinsic and extrinsic rewards. Researchers suggested that intrinsic factors has a significant impact on job satisfaction of employees. Intrinsic rewards cover some form of employee's job involvement, participate in decision making, job autonomy, task significance and recognition. The second group: extrinsic rewards cover social and organizational rewards. Social rewards refer those that can be derived from interaction with others on job and organizational rewards are the tangible rewards like pay, promotions, and other job related benefits. Rehman et al. (2010) found that extrinsic rewards are strong relationship with job satisfaction as compared to intrinsic rewards. According to Bjorkman and Budhwar (2007), private sector employees are motivated extrinsically by economic rewards. Srivastava (2004) and Zaini et al. (2009) noted that public sectors employees have greater needs for intrinsic rewards and intrinsic motivation. The reward is also defined as all cash, non-monetary and psychological payments that the organization provides to its employees (Bartol, and Locke, 2000).

Employing committed employees is essential to organizations, especially in case projectbased organizations, where projects have different constraints and require greater effort and input from employees. Organizational commitment is described as a psychological state that characterizes the employee's relationship with the organization, and has implications for the decision to continue or discontinue membership in the organization (Meyer et al., 1993). Commitment often results in positive outcomes, such as, increased efficiency, higher performance, reduced absenteeism and employee turnover (Suliman, and AlJunaibi, 2010). Organizational commitment is an antecedent of a number of important organizational constructs, such as: motivation, stress, job satisfaction, job involvement and turnover intentions (Bozeman, and Perrewe, 2001). According to Feldman (2000) organizational commitment is a psychological contract in which employees assure long- term loyalty and commitment towards the organization, whereas expecting job safety, chances for promotion and training in return. Organizational commitment is also defined as the strength of an individual's identification with and involvement in a particular organization (Bozeman, and Perrewe, 2001). Allen and Meyer (1990) proposed a three- dimensional attitudinal concept of organizational commitment that is: affective, normative and continuance commitment. Affective commitment refers as employees' psychological affiliation and emotional attachment to the organization (Allen, and Meyer, 1990). Normative commitment is described as employees' ethical responsibility to continue work for a long period with the organization (Allen, and Meyer, 1990). Finally, continuance commitment refers as the recognition of employee for the costs related to quitting organization (Allen, and Meyer, 1990). Organizational commitment is the level of capability of employees to identify themselves and participate actively in the organization who marked desire to maintain membership in the organization, trust and acceptance of the values and goals of the organization, and a willingness to work as closely as possible in the interests of the organization (Wardoyo, 2016). 
Work engagement is a positive work-relevant experience and condition of mind (Schaufeli, and Bakker, 2004; Sonnentag, 2003). Job satisfaction is positively related to work engagement, which was confirmed by empirical research, where work engagement contributes to positive changes in work and organizational variables (e.g. job satisfaction and performance) (Harter et al., 2002; Saks, 2006; Sonnentag, 2003). According to Simpson (2009) and Crawford et al. (2010), work engagement is related to job attitudes, such as job satisfaction and several empirical studies have reported that work engagement fosters job satisfaction (Alarcon, and Edwards, 2011; Giallonardo et al., 2010; Kamalanabhan, and Prakashsai, 2009; Saks, 2006). Work engagement, which has been described as a positive and satisfying psychological state of people in relation to their work, that makes them feel fully involved (Schaufeli, and Bakker, 2004). Work engagement is defined as a positive emotional state associate with the work, characterized by high levels of vigor, dedication, and absorption (Schaufeli et al. 2006; Schaufeli et al., 2002). Vigor is defined as high levels of energy and mental resilience while working, the willingness to invest efforts in one's work and persistence even in the face of difficulties, while dedication refers to a sense of significance, enthusiasm, inspiration, pride and challenge (Schaufeli et al. 2006; Schaufeli et al., 2002). Absorption refers to being fully concentrated and deeply engrossed in one's work, whereby time passes quickly and one has difficulties with detaching oneself from work (Schaufeli et al. 2006; Schaufeli et al., 2002). Work engagement is usually positively associated with mental and physical health, work performance (Bakker, and Demerouti, 2016; Bakker et al., 2008) and negatively to withdrawal behaviours, such as absenteeism and turnover (Agarwal et al., 2012; Bakker, and Demerouti, 2016; Timms et al., 2015).

\section{Methodology of research}

The sample of the study includes 17 cases of Polish consulting firms, and the fieldwork contains information from series of surveys (January 2018-January 2019). Project-based organizations refer to a variety of organizational forms that involve the creation of temporary systems for the performance of project tasks and produce complex services for their clients. Thiry (2011) states that PBOs conduct the majority of their activities as projects and/or privilege project over functional approaches, they can include: departments within functional organizations; matrix organizations; projectized organizations other forms of organizations that privilege a project approach for conducting their activities. Most project-based organizations are service firms (Sundbo, 1997). Consulting firms, which constitute research subject of this study, are focused on project organizing and project managing to produce and deliver professional services to their clients. Therefore consulting firms are a pure form of projectbased organizations. 
To analyze the data a set-theoretic approach was chosen, specifically fuzzy set Qualitative Comparative Analysis (fs/QCA). The fs/QCA 2.5 software developed by Ragin and Fiss (2008) used to analyze the data. Fs/QCA facilitates the analysis of how causal conditions jointly (as configurations) are linked to an outcome of interest (Fiss, 2011). By doing so, each individual observation, consisting of a complex set of causal conditions, is regarded as a whole.

Fs/QCA starts from the assumption that outcomes rarely have any single cause (Greckhamer et al., 2008), and the interplay of different causal conditions constitutes an outcome. The first stage of the analysis identifies the various factors that work in combination to influence job satisfaction in project - based organizations. The raw data was then calibrated into fuzzy sets (Ragin, and Fiss, 2008).

The relationship between multiple conditions can be best understood in terms of set memberships (Fiss, 2011; Ganter, and Hecker, 2014). All variables are calibrated into set membership values ranging from 0 (case is fully out of a set) to 1 (case is fully in the set) (Fiss, 2011; Woodside, 2013); 0.5 (crossover point) is the point of maximum ambiguity. While the continuum between these two extremes reflects varying degrees of membership, the crossover point represents cases that are neither in nor out of the set (Schneider et al., 2010). Based on the membership values, fs/QCA uses Boolean algebra to determine which combinations of conditions result in the outcome (Fiss, 2011). The analysis of sufficient conditions involves three steps (Fiss, 2011; Ragin, 2006): construction, preparation, and analysis of the truth table. Reduction of the truth table shows several useful statistics. Overall solution consistency indicates the degree to which the sub-set relationship holds for sufficiency. The overall solution coverage refers to the joint importance of all causal paths. Unique coverage of causal conditions is similar to unique $\mathrm{R}$-square calculations in regression analysis in that it illustrates the relative weight of each path by measuring the degree of empirical relevance of a certain cause or causal combination to explain the outcome. Reduction of the truth table is carried out by the Quine-McCluskey algorithm which provides a logical reduction of statements (Ragin, and Fiss, 2008). A necessity test was executed to examine whether there is a single condition in all configurations to job satisfaction. A condition is necessary when its consistency is above 0.9 (Skaaning, 2011), which indicates the degree to which a condition is present in all cases with the same outcome. In this study no necessary conditions were found.

The survey includes five scales (person organization fit, supervisor support, rewards, organizational commitment and work engagement) in the form of statements to which respondents indicate their level of agreement/disagreement on a five-point Likert scale. All item loadings are higher than 0.7 . An extensive review of the relevant literature supports the validity of the scales (see Table 1). 
Table 1.

Scales measurement

\begin{tabular}{|c|c|c|}
\hline Conditions & Adapted from & $\begin{array}{c}\text { Cronbach } \\
\text { Alpha }\end{array}$ \\
\hline $\begin{array}{c}\text { Person } \\
\text { organization fit }\end{array}$ & Construct was measured by 3-items from Cable and Judge (1996) & 0.87 \\
\hline $\begin{array}{c}\text { Supervisor } \\
\text { support }\end{array}$ & Construct was measured by 7 items from Graen and Uhl-Bien (1995) & 0.81 \\
\hline Rewards & $\begin{array}{c}\text { Rewards practices were measured using a 6-item proposed by Tessema } \\
\text { and Soeters (2006) }\end{array}$ & 0.82 \\
\hline $\begin{array}{c}\text { Organizational } \\
\text { commitment }\end{array}$ & $\begin{array}{c}\text { Construct was measured with a 9-item version of the } \\
\text { Organizational Commitment Questionnaire proposed by Bozeman and } \\
\text { Perrewe (2001) }\end{array}$ & 0.86 \\
\hline $\begin{array}{c}\text { Work } \\
\text { engagement }\end{array}$ & $\begin{array}{c}\text { Work engagement was measured by using the Utrecht Work } \\
\text { Engagement Scale (Schaufeli, et al., 2002). The Utrecht Work } \\
\text { Engagement Scale has 3 dimensions (Vigor, Dedication } \\
\text { and Absorption) with 17 items }\end{array}$ & 0.83 \\
\hline
\end{tabular}

Source: own study.

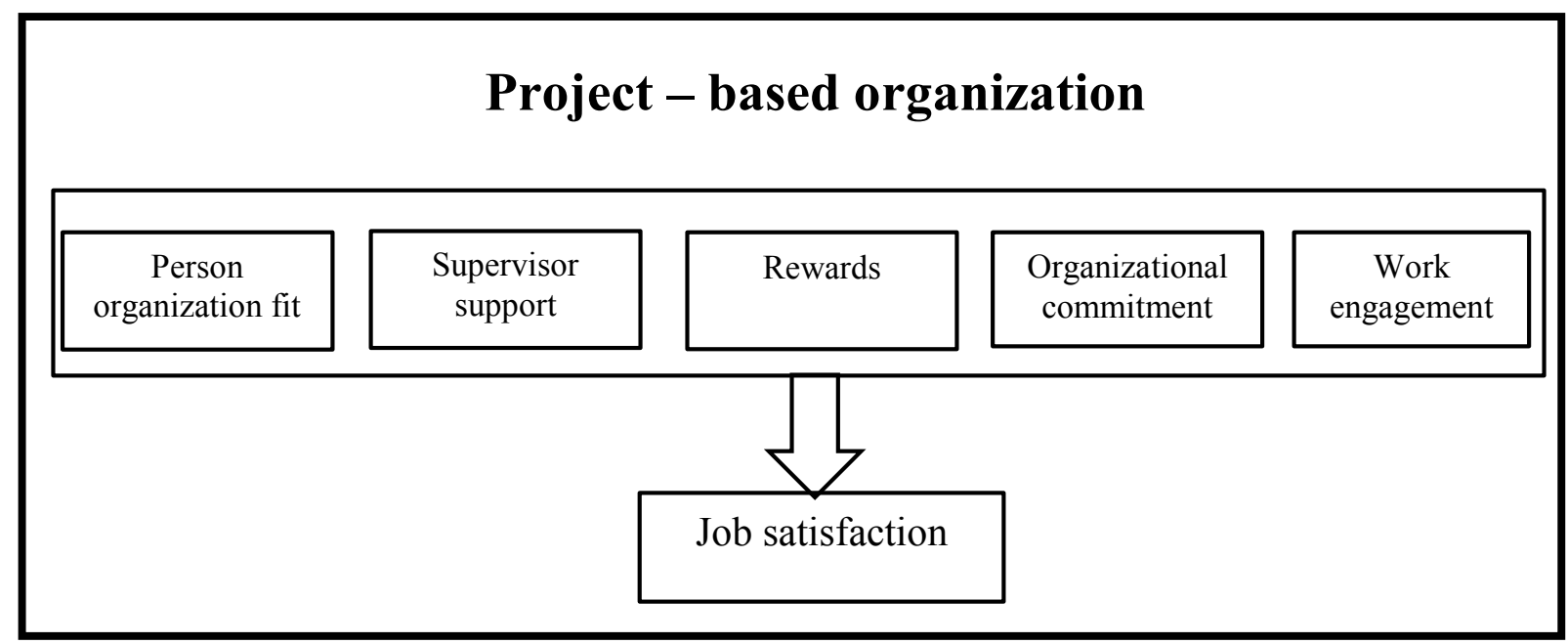

Figure 1. Conceptual model. Source: own study.

From a psychometric perspective, one single-item overall measure captures job satisfaction was used. The use of single-item measures to operationalize this construct (Cronbach Alpha = 0.929) compares favorably with the use of multiple-item measures (Dolbier et al., 2005). Research model is presented in a Figure 1 and it is verified in the process of scientific research.

\section{Results}

Based on the conceptual model presented above, a questionnaire was developed and series of surveys was carried out to collect data on job satisfaction in project - based organization. The results of empirical research was presented in Table 2 . In this table, each column represents a configuration of causal conditions with their corresponding raw coverage, unique coverage and solution consistency. The numbers at the bottom of the table represent the coverage and 
consistency of the solution as a whole. In brief, consistency measures the degree to which cases sharing a given condition agree in displaying an outcome. Raw coverage measures the overall coverage of a combination that may overlap with other combinations. Unique coverage refers to coverage uniquely due to a combination. Solution consistency measures the degree to which membership in the solution (the set of solution terms) is a subset of membership in the outcome. Lastly, solution coverage refers to the combined coverage of all combinations leading to the outcome (Ragin, 2008). The parsimonious and intermediate solutions were presented and analyzed (Ragin, and Fiss, 2008). Full circles (O) indicate the presence of a condition, while barred circles $(\Theta)$ indicate a condition's absence. Each panel represents the alternative causal combinations or recipes for the outcome (Ragin, 2008). These are consecutively numbered C1, $\mathrm{C} 2$ and $\mathrm{C} 3$.

Table 2.

Configurations of conditions

\begin{tabular}{|c|c|c|c|}
\hline \multirow{2}{*}{ Condition (factors) } & \multicolumn{3}{|c|}{ Configurations } \\
\hline & C1 & $\mathrm{C2}$ & C3 \\
\hline \multicolumn{4}{|l|}{ Person organization fit } \\
\hline \multicolumn{4}{|l|}{ Supervisor support } \\
\hline \multicolumn{4}{|l|}{ Rewards } \\
\hline \multicolumn{4}{|l|}{ Organizational commitment } \\
\hline \multicolumn{4}{|l|}{ Work engagement } \\
\hline Consistency & 0,81 & 0,86 & 0,75 \\
\hline Raw coverage & 0,45 & 0,34 & 0,39 \\
\hline Unique coverage & 0,27 & 0,19 & 0,26 \\
\hline Solution consistency & & 0,83 & \\
\hline Solution coverage & & 0,57 & \\
\hline
\end{tabular}

Source: own study.

According to the results of the analysis, the solution yields coverage close to $57 \%$ and consistency of $83 \%$. The first configuration of the conditions $\mathrm{C} 1$ combines person organization fit, supervisor support and organizational commitment. This configuration indicate that congruence between individual and organizational values and the degree to which employees perceive that supervisors care about their well-being, and psychological contract in which employees assure long- term loyalty and commitment towards the organization, whereas expecting job safety, chances for promotion and training in return, affect job satisfaction in project-based organization. The second configuration C2 combines rewards, organizational commitment and work engagement with absence of supervisor support. This configuration indicate that the broad construct that has been said to represent anything that an employee may value that an employer is willing to offer in exchange for his or her contributions, and a psychological state that characterizes the employee's relationship with the organization and has implications for the decision to continue or discontinue membership in the organization, and a positive and satisfying psychological state of people in relation to their work, that makes them feel fully involved without supervisor support in terms of emotional or instrumental and without supervisor's feedback, lead to job satisfaction. Despite of there is no supervisor support, 
rewards and organizational commitment with work engagement influence job satisfaction in PBO. The third configuration $\mathrm{C} 3$ combines person organization fit, rewards and work engagement. This configuration indicate that the compatibility of individual and organizational beliefs and values, and all cash, non-monetary and psychological payments that the organization provides to its employees, and a positive emotional state associate with the work, characterized by high levels of vigor, dedication and absorption, lead to job satisfaction.

\section{Conclusion}

Whereas organizations that are not project based make their income mainly through production, project-based organizations derive their income from projects. In companies where the primary business consists of performing projects for clients, it is projects that generate both revenue and profits (Rietiker, 2013). Projects have different constraints and require high-quality workforce and greater effort and input from employees, i.e. for a project-based organization, success in project execution, which is the basis of the business, depends on people who realize the project. Job satisfaction is an essential factor That affects employees' initiative, enthusiasm and engagement in work, that's why achieving job satisfaction by employees in project-based organization may influence the success of whole project. Examining the variables that create configurations of factors which lead to job satisfaction in project-based organizations is important from the organizational point of view, because it can indicate the future directions of activities for achieve a higher level of employee satisfaction, which will translate into the success of the entire PBO. Using of fs/QCA, enabled simultaneous studying the effect of selected factor and it is an original contribution to the research on job satisfaction in PBO.

The results of research have practical implications for managers of project-based organization, because they provide them with configuration of factors which lead to job satisfaction. Specially, (C1): person organization fit, supervisor support and organizational commitment and (C2): rewards, organizational commitment and work engagement with absence of supervisor support and (C3): person organization fit, rewards and work engagement influence job satisfaction in project- based organization.

This research has several limitations. The first of them relates to the data source. The data in this study come from a limited research sample - consulting firms operating in Polish country, which may reduce the generalizability of the results. Future research could replicate this study in other and countries. Second, this study considered and examined few factors of job satisfaction selected based on critical analysis of the literature and future studies could include other variables. 


\section{References}

1. Agarwal, U.A., Datta, S., Blake-Beard, S., and Bhargava, S. (2012). Linking LMX, innovative work behaviour and turnover intentions: The mediating role of work engagement. Career Development International, 17(3), 208-230. http://dx.doi.org/ $10.1108 / 13620431211241063$.

2. Alarcon, G.M., and Lyons, J.B. (2011). The relationship of engagement and job satisfaction in working samples. The Journal of Psychology, 145(5), 463-480. http://dx.doi.org/10. 1080/00223980.2011.584083.

3. Albrecht, S., Bakker, A., Gruman, J., Macey, W., and Saks, A. (2015). Employee engagement, human resource management practices and competitive advantage: An integrated approach. Journal of Organizational Effectiveness: People and Performance, 2, 7-35.

4. Allen, N.J., and Meyer, J.P. (1990). The measurement and antecedents of affective, continuance and normative commitment to the organization. Journal of Organizational Psychology, 63 (1), 1-18.

5. Anderson, S.E., Coffey, B.S., and Byerly, R.T. (2002). Formal organizational initiatives and informal workplace practices: Links to work-family conflict and job-related outcomes. Journal of Management, 28(6), 787-810.

6. Armstrong, M., and Murlis, H. (2004). Reward Management. London: Kogan Page.

7. Aubry, M., Richer, M.C., Lavoie-Tremblay, M. (2014). Governance performance in complex environment: The case of a major transformation in a university hospital. International Journal of Project Management, 32, 1333-1345. doi:10.1016/j.ijproman. 2013.07.008.

8. Bakker, A.B. and Demerouti, E. (2016). Job demands - Resources theory: Taking stock and looking forward. Journal of Occupational Health Psychology, 1-13, 273-285. http://dx.doi.org/ 10.1037/ocp0000056.

9. Bakker, A.B., Schaufeli, W.B., Leiter, M.P., and Taris, T.W. (2008). Work Engagement: An Emerging Concept in Occupational Health Psychology. Work \& Stress, 22, 187-200.

10. Bartol, K.M., and Locke, E.A. (2000). Incentives and motivation. In: S.L. Rynes, B. Gerhart (Eds.), Compensation in Organizations (pp. 104-147). Current Research and Practice. San Francisco, CA: Jossey-Bass.

11. Bjorkman, I., and Budhwar, P. (2007). When in Rome? Human resource management and the performance of foreign firms operating in India. Employee Relations, 29(6), 595-610.

12. Bozeman D.P., and Perrewe P.L. (2001). The effects of item content overlap on Organizational Commitment Questionnaire-turnover cognitions relationships. Journal of Applied Psychology, 86, 161-173. 
13. Bredin, K. (2006). Human Resource Management in Project-Based Organisations: Challenges, Changes, and Capabilities. Doctoral thesis. Linköping: Department of Management and Engineering, Linköping University.

14. Brown, S.L., and Eisenhardt, K.M. (1997). The Art of Continuous Change: Linking Complexity Theory and Time-paced Evolution in Relentlessly Shifting Organizations. Administrative Science Quarterly, 42, 1-34. doi:10.2307/2393807.

15. Cable, D., and Judge, T. (1996). Person-Organization Fit, Job Choice Decisions. Organizational Behavior and Human Decision Processes, 67, 294-311.

16. Cacciatori, E. (2008). Memory objects in project environments: storing, retrieving and adapting learning in project-based firms. Research Policy, 37, 1591-1601.

17. Cahill, K.E., McNamara, T.K., Pitt-Catsouphes, M., and Valcour, M. (2015). Linking shifts in the national economy with changes in job satisfaction, employee engagement and worklife balance. Journal of Behavioral and Experimental Economics, 56, 40-54.

18. Cattani, G., Ferriani, S., Frederiksen, L., and Täube, F. (2011). Project-Based Organizing and Strategic Management: A Long-Term Research Agenda on Temporary Organizational Forms (Editorial). Advances in Strategic Management, 28, xv-xxxix.

19. Chahal, A., Chahal, S., Chowdhary, B., and Chahal, J. (2013). Job Satisfaction Among Bank Employees: An Analysis Of The Contributing Variables Towards Job Satisfaction. International Journal Of Scientific Technology Research, 2(8), 11-20.

20. Chiang, F.F.T., and Birtch, T.A. (2008). Achieving task and extra-task-related behaviors: a case of gender and position differences in the perceived role of rewards in the hotel industry. International Journal of Hospitality Management, 27(4), 491-503

21. Christiansen, N., Villanova, P., and Mikulay, S. (1997). Political influence compatibility: fitting the person to the climate. Journal of Organizational Behavior, 18 (6), 709-30.

22. Crawford, E.R., Lepine, J.A., Rich, B.L., and Demerouti, E. (2010). Linking job demands and resources to employee engagement and burnout: A theoretical extension and metaanalytic test. Journal of Applied Psychology, 95(5), 834-848. http://dx.doi.org/ $10.1037 / \mathrm{a} 0019364$.

23. Danish, R., and Usman, A. (2010). Impact of Reward and Recognition on Job Satisfaction and Motivation: An Empirical Study from Pakistan. International Journal of Business and Management, 5(2), 195-167.

24. De Clercq, D., Dimov, D., and Belausteguigoitia, I. (2016). Perceptions of adverse work conditions and innovative behavior: The buffering roles of relational resources. Entrepreneurship: Theory and Practice, 40(3), 515-542. https://doi.org/10.1111/ etap. 12121.

25. Deming, E. (2014). The Seven Deadly Diseases'. Retrieved from: https://www.deming.org/theman/theories/deadlydiseases, 19.01.2018. 
26. Dolbier, C.L., Webster, J.A., McCalister, K.T., Mallon, M.W. and Steinhardt, M.A. (2005). Reliability and validity of a single-item measure of job satisfaction. American Journal of Health Promotion, 19, 194-198.

27. Ebers, M., and Powell, W. (2007). Biotechnology: its origins, organization, and outputs. Research Policy, 36, 433-437.

28. Edwards, J., Cable, D.M, Williamson, I.O, Lambert, L.S., Shipp, A.J. (2006). The phenomenology of fit: Linking person and environment to the subjective experience of person environment fit. Journal of Applied Psychology, 91(4), 802-827.

29. Faroqui, S., and Nagendra, A. (2014). The Impact of person organization fit on job satisfaction and performance of the employees. Procedia economics and Finance, $11,122-129$.

30. Feldman, D. (2000). The dilbert syndrome: how employee cynicism about ineffective management is changing the nature of careers in organizations. American Behavioral Scientist, 43, 1286-301.

31. Fiss, C. (2011). Building better causal theories: A fuzzy set approach to typologies in organization research. Academy of Management Research, 54(2), 393-420.

32. Freilich, J. (2015). When Innovation Is Not Enough. The Managerial Challenges of Technology Change in Pharmaceutical R\&D. KTH Royal Institute of Technology.

33. Ganter, A., and Hecker, A. (2014). Configurational paths to organizational innovation: Qualitative comparative analyses of antecedents and contingencies. Journal of Business Research, 67(6), 1285-1292.

34. Garcez, C. (2006). Job Satisfaction: The Challenges Transformed Organizations Face. Retrieved from: http://aplawrence.com/Misc/job_satisfaction.html, 29.01.2018.

35. Giallonardo, L.M., Wong, C.A., and Iwasiw, C.L. (2010). Authentic leadership of preceptors: Predictor of new graduate nurses' work engagement and job satisfaction. Journal of Nursing Management, 18(8), 993-1003.

36. Graen, G.B., and Uhl-Bien, M. (1995). Relationship-based approach to leadership: Development of leader-member exchange (LMX) theory of leadership over 25 years: Applying a multi-level multi-domain perspective. Leadership Quarterly, 6(2), 219-247.

37. Greckhamer, T., Misangyi, V.F., Elms, H., and Lacey, R. (2008). Using qualitative comparative analysis in strategic management research. Organizational Research Methods, 11(4), 695-726.

38. Harter, J.K., Schmidt, F.L., and Hayes, T.L. (2002). Business-Unit-Level Relationship Between Employee Satisfaction, Employee Engagement, and Business Outcomes: A MetaAnalysis. Journal of Applied Psychology, 87, 268-279.

39. Hobday, M. (1998). Product complexity, innovation and industrial organization. Research Policy, 26, 689-710. 
40. Hoonakker, P., Carayon, P., and Korunka, C. (2013). Using the job-demands-resources model to predict turnover in the information technology workforce - General effects and gender differences. Horizons of Psychology, 22, 51-65.

41. Jansen, K.J., and Kristof, A. (2006). Toward a Multidimensional Theory of PersonEnvironment Fit. Journal of Managerial Issues, 18, 193-212.

42. Kamalanabhan, T.J., and Prakashsai, L. (2009). Employee engagement and job satisfaction in the information technology industry. Psychological Reports, 105(3), 759-770.

43. Kiviniemi, M. T., Snyder, M., and Omoto, A. M. (2002). Too many of a good thing? The effects of multiple motivations on stress, cost, fulfillment, and satisfaction. Personality and social psychology bulletin, 28(6), 732-743. https://doi.org/10.1177/ 0146167202289003.

44. Kristof, A.L. (1996). Person-organisation fit: an integrative review of its conceptualizations, measurement, and implications. Personnel Psychology, 49, 1-50.

45. Loufrani-Fedida, S., and Saglietto, L. (2016). Mechanisms for Managing Competencies in Project-Based Organizations: An Integrative Multilevel Analysis. Long Range Planning, 49, 72-89. doi:10.1016/j.lrp.2014.09.001.

46. Lundin, R.A., Arvidsson, N., Brady, T., Ekstedt, E., Midler, C., and Sydow, J. (2015). Managing and Working in Project Society: Institutional Challenges of Temporary Organizations. Cambridge: Cambridge University Press, UK. doi:10.1007/ 9781139939454.

47. Luthans, K.W., and Sommers, S.M. (2005). The impact of high performance work on industry level outcomes. Journal of Managerial Issues, 17(3), 327-345.

48. Meyer, J.P., Allen, N.J., and Smith, C.A. (1993). Commitment to organizations and occupations: Extension and test of a three-component conceptualization. Journal of Applied Psychology, 78, 538-551.

49. Mietrev, M., Mancini, M., and Turner, R. (2017). Towards a design for the project-based organization. International Journal of Project Management, 35, 479-491.

50. Netemeyer, R.G., Boles, J.S., McKee, D.O., and McMurrian, R. (1997). An investigation into the antecedents of organizational citizenship behaviors in a personal selling context. Journal of Marketing, 61(3), 85-98.

51. Putter, S.E. (2013). Making training stick: a close examination of how trainee readiness, supervisor support, and practice foster transfer in a mobile technology based training program. PhD Dissertation. Retrieved from: https://dspace.library.colostate.edu/bitstream/ handle/10217/80969/Putter_colostate_0053A_12035.pdf?sequence=1, 17.01.2018.

52. Rafikul, I., and Ahmad, Z.I. (2008). Employee motivation: A Malaysian perspective. International Journal of Commerce and Management, 18(4), 344-362.

53. Ragin, C.C. (2006). Set relations in social research: Evaluating their consistency and coverage. Political Analysis, 14(3), 291-310. 
54. Ragin, C.C. (2008). User's guide to fuzzy-set/qualitative comparative analysis. Retrieved from www.fsqca.com.

55. Ragin, C.C., and Fiss P. (2008). Net effects versus configurations: an empirical demonstration. In: C.C. Ragin (Ed.), Redesigning Social Inquiry, 1, 190-212. ChicagoLondon: University of Chicago Press.

56. Raziq, A., and Maulabakhsh, R. (2015). Science Direct Impact of Working Environment on Job Satisfaction. Procedia Economics and Finance, 23, 717-725.

57. Rehman, M.Z.U., Khan, M.R., Ziauddin, Lashari, J.A. (2010). Effect of job rewards on job satisfaction, moderating role of age differences: an empirical evidence from Pakistan. African Journal of Business Management, 4(6), 1131-1139.

58. Rowold, J., Borgmann, L., and Bormann, K. (2014). Which leadership constructs are important for predicting job satisfaction, affective commitment, and perceived job performance in profit versus nonprofit organizations? Nonprofit Management and Leadership, 25(2), 14--164.

59. Saks, A.M. (2006). Antecedents and Consequences of Employee Engagement. Journal of Managerial Psychology, 21, 600-619.

60. Santos, L.B.D., and De Domenico, S.M.R. (2015). Person-organization fit: Bibliometric study and research agenda. European Business Review, 27(6), 573-92.

61. Schaufeli, W.B., and Bakker, A.B. (2004). Job demands, job resources, and their relationship with burnout and engagement: A multi-sample study. Journal of Organizational Behavior, 25(3), 293-315.

62. Schaufeli, W.B., Salanova, M., Gonzales-Roma, V., and Bakker, A.B. (2002). The measurement of engagement and burnout: A two sample confirmatory factor analytic approach. Journal of Happiness Studies, 3(1), 71-92.

63. Schaufeli, W.B., Bakker, A.B., and Salanova, M. (2006). The Measurement of Work Engagement With a Short Questionnaire: A Cross-National Study. Educational and Psychological Measurement, 66, 701-716.

64. Sharma, S., Sharma, J., and Devi, A. (2009). Corporate Social Responsibility: The Key Role of Human Resource Management. Business Intelligence Journal, 2(1),205-213.

65. Simpson, M.R. (2009). Engagement at Work: A Review of the Literature. International Journal of Nursing Studies, 46, 1012-1024.

66. Skaaning, S.E. (2011). Assessing the robustness of crisp-set and fuzzy-set QCA results. Sociological Methods and Research, 40(2), 1-18.

67. Snips, L.R., Oswald, L.S., laTour, M., and Armenskis, A.A. (2008). The effects of specific job satisfaction facets on customer perceptions of service quality. Industrial Marketing Management, 58, 921-939.

68. Suliman, A.A., and Al-Junaibi, Y. (2010). Commitment and turnover intention in the UAE oil industry. Intentional Journal of Human Resource Management, 21(9), 1472-89. 
69. Sundbo, J. (1997). Management of innovation in services. The Service Industries Journal 17 (3), 432-455.

70. Sydow, J., and Windeler, A. (1998). Organizing and Evaluating Interfirm Networks: A Structurationist Perspective on Network Processes and Effectiveness. Organization Science, 9(3), 265-284.

71. Sydow, J., Lindkvist, L., and De Fillippi, R. (2004). Project-based organizations, embeddedness, and repositories of knowledge: editorial. Organization Studies, 25(9), 1475-1489. doi:10.1177/0170840604048162.

72. Tessema, M., and Soeters, J. (2006).Challenges and prospects of HRM in developing countries: testing the HRM-performance link in Eritrean civil service. International Journal of Human Resource Management, 17(1), 86-105.

73. Thiry, M. (2011). From PMO to PBO: The PMO as a Vehicle for Organizational Change. PM World Today XIII (1), 11-19.

74. Thiry, M., and Deguire, M. (2007). Recent developments in project-based organizations. International Journal of Project Management, 25, 649-658.

75. Timms, C., Brough, P., O'Driscoll, M., Kalliath, T., Siu, O.L., Sit, C., and Lo, D. (2015). Flexible work arrangements, work engagement, turnover intentions and psychological health. Asia Pacific Journal of Human Resources, 53(1), 83-103. http://dx.doi. org/10.1111/1744-7941.12030.

76. Trocki, M. (2016). Projektowanie organizacji projektowej. In: M. Trocki, and E. Bukłaha (Eds.), Zarzadzanie projektami - wyzwania $i$ wyniki badań. Warszawa: Oficyna Wydawnicza SGH.

77. Van der Klink, J., Blonk, R., Schene, A.H., and Van Dijk, F. (2001). The benefits of interventions for work-related stress. American journal of public health, 91(2), 270-281.

78. Van Vianen, A.E.M., Shen, C.T., and Chuang, A. (2011). Person-organization and personsupervisor fits: Employee commitments in a Chinese context. Journal of Organizational Behavior, 32, 906-926.

79. Woodside, A.G. (2013). Moving beyond multiple regression analysis to algorithms: Calling for adoption of a paradigm shift from symmetric to asymmetric thinking in data analysis and crafting theory. Journal of Business Research, 66, 463-472.

80. Zaini, A., Nilufar, A., Syed, S.A. (2009). The effect of human resource management practices on business performance among private companies in Malaysia. International Journal of Business and Management, 4(6), 65-72. 